\title{
Antibacterial Potency of Ozonated Water against Escherichia coli
}

\author{
Syarifa Fitria ${ }^{1}$, Zolkafle Buntat ${ }^{2}$, Zainuddin Nawawi ${ }^{3 *}$, Muhammad Abu Bakar Sidik³, \\ M.I. Jambak ${ }^{3}$ and Dwirina Yuniarti ${ }^{3}$
}

${ }^{1}$ Graduate School of Environmental Science, University of Sriwijaya, Palembang, South Sumatra 30128, Indonesia. ${ }^{2}$ Institute of High Voltage and High Current, Faculty of Electrical Engineering, Universiti Teknologi Malaysia, Johor Baru 81310, Malaysia. ${ }^{3}$ Department of Electrical Engineering, Faculty of Engineering, University of Sriwijaya, Palembang, South Sumatra 30128, Indonesia.

\begin{abstract}
Sterilization is essential for inactivation of microorganisms. There are many methods of sterilization, such as the use of heat or chemical processes. However, some equipment can be damaged by heat and can only be sterilized at low temperatures. Failure to properly disinfect or sterilize equipment may lead to transmission via contaminated objects. This paper presents a sterilization process using ozonized water at a temperature of $29.5^{\circ} \mathrm{C}$ with gram-negative bacteria (Escherichia coli). The antibacterial effect was examined with various concentrations of ORP (oxidation reduction potential) at $702 \mathrm{mV}, 802 \mathrm{mV}$, $940 \mathrm{mV}, 950 \mathrm{mV}$, and $960 \mathrm{mV}$. A strong linear correlation was observed between ORP value and the surface area of the antibacterial effect. It was found that increasing the concentration of ORP affects the surface area of Escherichia coli.

Keywords: Antibacterial, E. coli, ozonated water, oxidation reduction potential.
\end{abstract}

\footnotetext{
*Correspondence: nawawi_z@yahoo.com+62-711-580069

(Received: 24 October 2018; accepted: 07 December 2018)

Citation: Syarifa Fitria, Zolkafle Buntat, Zainuddin Nawawi, Muhammad Abu Bakar Sidik M.I. Jambak and Dwirina Yuniarti, Antibacterial Potency of Ozonated Water against Escherichia coli, J Pure Appl Microbiol., 2019; 13(1):637-641 doi: 10.22207/ JPAM.13.1.73

C The Author(s) 2019. Open Access. This article is distributed under the terms of the Creative Commons Attribution 4.0 International License which permits unrestricted use, sharing, distribution, and reproduction in any medium, provided you give appropriate credit to the original author(s) and the source, provide a link to the Creative Commons license, and indicate if changes were made.
} 


\section{INTRODUCTION}

Sterilization is important for inactivation of microorganisms, providing improved good quality of life for humans. Inactivation of a microorganism includes its destruction or elimination by physical or chemical processes or a combination of the both $^{1}$. Application of conventional sterilization methods, such as using high temperature, high pressure, chemical gas, and radiation (gamma rays), depends on the type of materials being sterilized.

Although some methods using high temperature and high pressure are effective in inactivating microorganisms, they are inefficient regarding sterilization duration, energy consumption, and plastic equipment application $^{1,2,3}$. Sterilization using chemicals, gas, and radiation can be applied to many types of equipment. However, the method will produce toxic residues, change molecular structure (crosslink or scissor), release odors, change $\mathrm{pH}$, cause discoloration and degradation of a few materials, or affect bond strengths and change over the shelf life of the material ${ }^{3}$.

Another way to sterilize is through the use of ozone as a disinfectant. Use of ozone and ionized water is an environmentally friendly method for inactivation of bacterial4,5. Ozone is a powerful and effective germicidal oxidant that has great potential over chlorine (chemical method) and other disinfectant methods. Ozone is currently used as a disinfectant for water, air, and various pharmaceutical applications $\mathrm{s}^{6,7,8}$. The most common method for ozone generation is Dielectric Barrier Discharge (DBD). The DBD model is shown in Fig. 1. This method consists of at least one insulating layer between two electrodes or cylindrical electrodes that connect to an AC power supply with a dielectric layer.

Homogeneous discharges produced in the air gap between the electrodes-the volume of the reaction chamber-cause the temperature in the chamber to remain low $\left(25^{\circ} \mathrm{C}\right)$, which reduces the need for a cooling system ${ }^{9,10,11}$. Dry air or oxygen that is supplied in the DBD chamber allows the dissociation of oxygen molecules to form ozone. In 2001, ozone in the gaseous and aqueous phases was accepted by the U.S. Food and Drug Administration (US FDA) as an antimicrobial agent for the treatment, storage, and processing of foods ${ }^{12}$.

Ozone has decomposition products which can rapidly inactivate microorganisms (e.g., hydroxyl radical) by reacting with intracellular enzymes, nucleic material, and components of the cell envelope ${ }^{12}$. Inactivation of bacteria using ozone causes leakage of inner contents due to oxidation of unsaturated lipids in the cell envelope, which finally results in cell lysis ${ }^{12,13,14}$. The mechanism most referred to in the formation of ozone in electrical discharge is the following chemical reaction ${ }^{15,16,17,18}$.

$$
\begin{aligned}
& \mathrm{e}^{-}+\mathrm{O}_{2} \rightarrow 2 \mathrm{O}+\mathrm{e}^{-} \\
& \mathrm{O}+\mathrm{O}_{2}+\mathrm{M} \rightarrow \mathrm{O}_{3}+\mathrm{M}
\end{aligned}
$$

$M$ is a third component necessary to support the reaction when the air is injected. $M$ could be gas molecules such as oxygen, helium, or argon.

In the reaction, electron bombardment breaks oxygen molecules apart; electrons that avalanche will recombine with each other or with the other oxygen molecules for ozone formation ${ }^{15}$. The method used in this experiment aimed to detect the extent that dissolved ozone mixed with distilled water was monitored through the ORP meter. ORP is well-known to have higher efficiency in inactivating bacteria with higher values ${ }^{19}$.

Failure to properly disinfect or sterilize equipment may lead to transmission via contaminated objects. The objective of this study was to observe whether the ozonized water with different concentrations of ORP could develop an inhibition zone for Escherichia coli. The linear

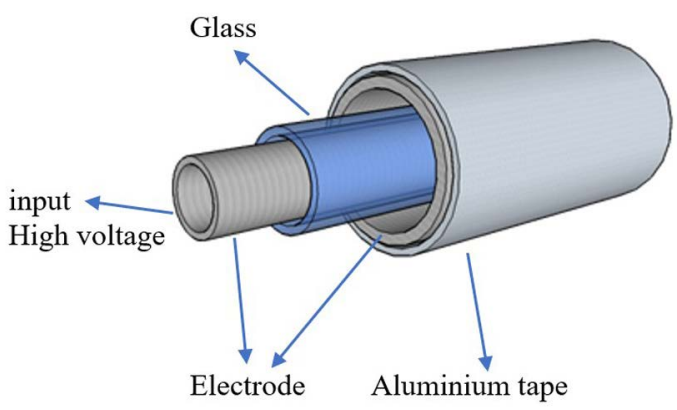

Fig. 1. Dielectric Barrier Discharge model. [Change aluminum to aluminum. Change to High voltage input] 
correlation between surface area and rate of oxidation-reduction potential used in ozonized water was examined.

\section{MATERIALS AND METHODS}

Escherichia coli ATC9222 was used as a sample for indicating contaminated objects. At first, the Escherichia coli was developed in Nutrient Agar slant and then transferred to a nutrient broth composed of $0.65 \mathrm{~g}$ and $50 \mathrm{ml}$ of distilled water, and incubated for 24 hours at $35^{\circ} \mathrm{C}$. Samples in the nutrient broth that were grown for 24 hours were spread into a petri dish (Anumbra, $100 \times 15$ $\mathrm{mm}^{2}$ ). Whatman papers were placed into the petri dish that already dyes into the ozonized water. The results were obtained after the petri dish incubated for 24 hours at $35^{\circ} \mathrm{C}$.
Ozone was generated using a dielectric barrier discharge system with an applied voltage of $15 \mathrm{kV}$ at atmospheric pressure. Oxygen with a purity of $99.9 \%$ was injected into the ozone generator at a constant flow rate of $0.5 \mathrm{l} / \mathrm{min}$. Electron avalanches processed in the electric field led to the creation of partially ionized plasma and created ozone. Ozone was mixed with distilled water by using a Venturi Injector and a static mixer. From the static mixer, the ozonated water was collected in a bottleneck tube. The ozonated water was measured by an ORP meter (AZ Instrument 8551) and a pH meter (Hanna HI 98107) to analyze the correlation of ORP and $\mathrm{pH}$ with the surface area containing Escherichia coli in the petri dish (Fig. 2).

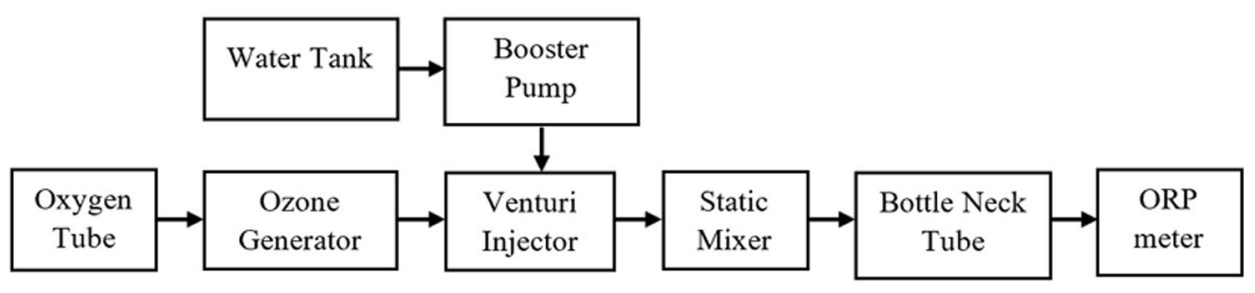

Fig. 2. Experimental setup

The ozonated water in various concentrations of oxidation-reduction potential (702 mV, $802 \mathrm{mV}, 940 \mathrm{mV}, 950 \mathrm{mV}$, and $960 \mathrm{mV}$ ) was injected into Whatman papers and then put into a petri dish already containing Escherichia coli in EMB (eosin methylene blue) media. Formed inhibition zones were obtained after the petri dish was incubated for 24 hours at $35^{\circ} \mathrm{C}$. The circular transparent zones in the exposed samples represent the growth of the inhibition zone. They could be observed directly without special equipment and the diameter measured by using a ruler (1 $\mathrm{mm}$ precision).

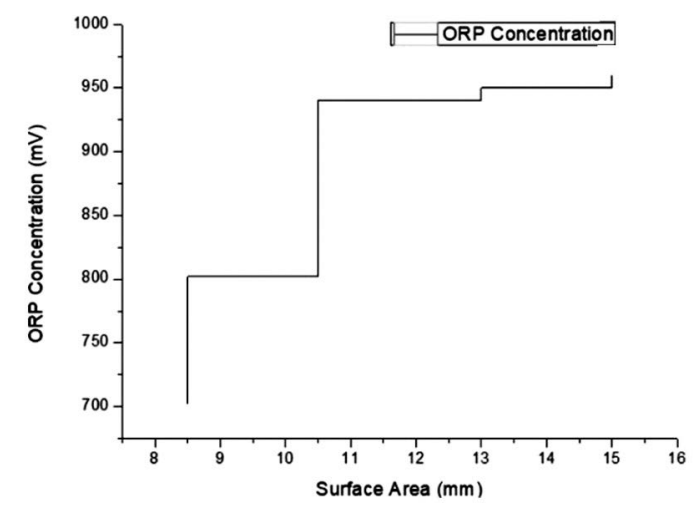

Fig. 3. ORP concentration vs surface area

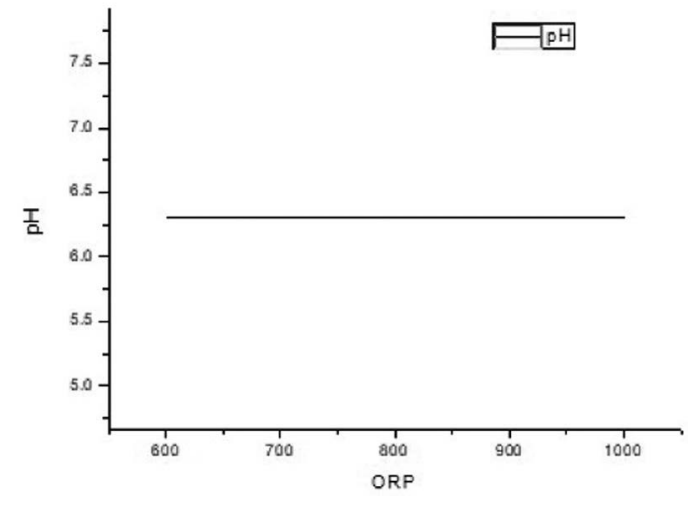

Fig. 4. $\mathrm{pH}$ vs ORP concentration 


\section{RESULTS AND DISCUSSION}

The addition of ozone to the distilled water gives a relatively linear result of changes in the surface area with the different oxidationreduction potential concentrations used. Fig. 3 provides information on the antibacterial effects on Escherichia coli tested with ORP.

The width of the surface area in the Escherichia coli stained with EMB shows a beneficial contribution of ozonated water to bacterial growth elimination. The observation of an inhibition zone against bacterial growth was carried out in various concentration over 3 days. At a low concentration of $702 \mathrm{mV}$, as shown in Fig. 3, the inhibition zone was limited only to the surface area, even in 3 days of observation. As shown in Fig. 4, when using a concentration of $960 \mathrm{mV}$, the inhibition zone was more significant than in lower concentrations, and no modification was seen in 3 days. This proves that high concentrations of ozonated water can create a beneficial inhibition zone against Escherichia coli, as shown in Fig. 5.

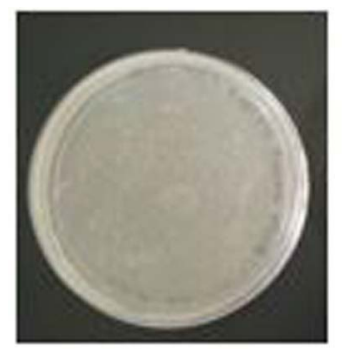

(a)

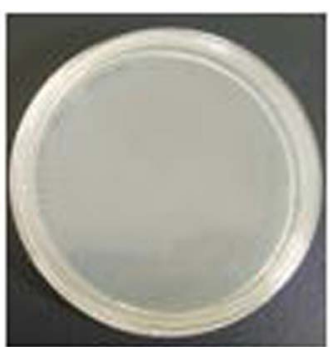

(b)
Fig. 5. Inhibition zones against Escherichia coli

The ORP value gives the potential redox level of the ozonated water, which has an oxidation value that acts to inhibit and inactivate bacteria. During the inhibition process, the ORP value indicates the oxidative agents whereas $\mathrm{pH}$ remained stable. This result agrees with the findings of Wang et al. ${ }^{20}$, oxidation was not influenced by low $\mathrm{pH}$, suggesting that oxidation plays an important role during the process. Based on Fig. 6a and Fig. 6b, ozonated water is able to inactivate Escherichia coli, there was no growth after incubation for 24 hours at $35^{\circ} \mathrm{C}$. This result has a good agreement with evidence that ozone is known to have antibacterial activity ${ }^{21,22}$ (Fig. 5).

Additional distilled water creates an electron impact reaction in the impulse stage, also generating $\mathrm{H}$ and $\mathrm{OH}$ radicals that are able to inactivate bacteria ${ }^{16}$. The ORP was considered to be a more suitable indicator for the optimal operation of the antibacterial process (Fig. 6a and Fig.6b).

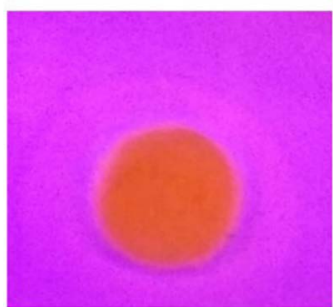

$802 \mathrm{mV}$

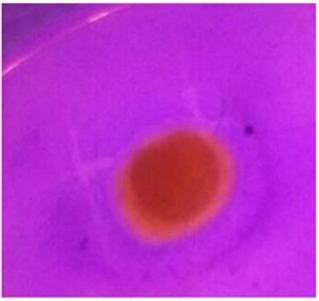

$950 \mathrm{mV}$

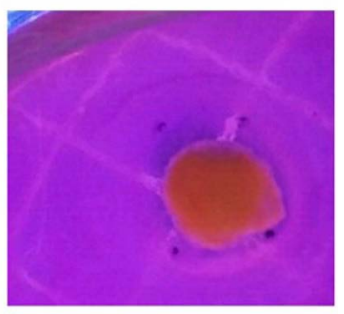

$940 \mathrm{mV}$

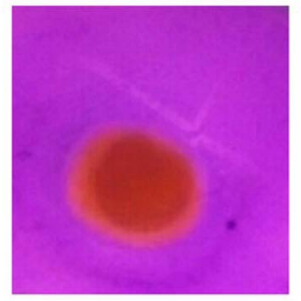

$960 \mathrm{mV}$
Fig. 6. a. Before treatment; b. After treatment

\section{CONCLUSION}

Ozone is known as an antibacterial agent. Ozone mixed with distilled water, that is, ozonated water, has good results for increasing the inhibition zone against Escherichia coli. The ORP concentration in ozonated water plays an important role as an oxidative agent for inhibition and inactivation of bacteria but the $\mathrm{pH}$ value was almost stable in the entire process. Since, the electron that oxidized in water could affect bacteria growth around surface area.

Further research is needed on the oxidation-reduction potential for other bacteria to determine the inhibition zone at various concentrations and subsequent cell damage after exposure to ozonated water. The proposed system may find future use as a means for sterilizing medical equipment using ozone generated and mixed with distilled water.

\section{ACKNOWLEDGEMENTS}

This research was supported by the Ministry of Research, Technology, and Higher Education of the Republic of Indonesia through the PMDSU Scholarship for first author. 


\section{COFLICT OF INTEREST}

The author declares that there is no conflict of interest.

\section{REFERENCES}

1. Chiang MH, Wu JY, Li YH, Wu JS, Chen SH and Chang CL. Inactivation of $E$. coli and $B$. subtilis by a parallel-plate dielectric barrier discharge jet. Surf Coat Tech, 2010; 204(21-22): 3729-3737.

2. Tanino M, Xilu W, Takashima K, Katsura S, and Mizuno A. Sterilization using Dielectric Barrier Discharge at Atmospheric Pressure. Int J Plasma Environ. Sci. Technol., 2007; 1(1): 102-107.

3. Rogers WJ. 2013. 4 - The effects of sterilization on medical materials and welded devices, pp. 79230. Woodhead Publishing Series in Bio-materials, Cambridge.

4. Bouregba N, Benmimoun $\mathrm{Y}$, Meddah $\mathrm{B}$, and Ouldmoumna A. Ozonation of wastewater in Algeria by dielectric barrier discharge. Desalin Water Treat, 2016; 57(4): 1824-1835.

5. Huang $\mathrm{Y}$, Kou $\mathrm{Y}$, Zheng $\mathrm{C}, \mathrm{Xu} \mathrm{Y}$, Liu $Z$, and Yan $\mathrm{K}$. Escherichia coli Inactivation in Water USing Pulsed Discharged. IEEE T Plasma Sci, 2016; 44(6): 1-6.

6. Song $Y$, Liu $D$, Lu $Q$, Xia $Y$, Zhou R, Yang D, and Wang W. An Atmospheric-Pressure Large-Area Diffuse Used for Disinfection Application, IEEE T Plasma Sci, 2015; 43(3): 821-827.

7. Fridman A, Chirokov A, and Gutsol A. Non-thermal atmospheric pressure discharges. J. Phys. D. Appl. Phys., 2005; 38(2): 1-10

8. Hunt NK and Marioas BJ. Inactivation of Escherichia coli with ozone: Chemical and inactivation kinetics. Water Res, 1999; 33(11): 2633-2641.

9. Bogaerts A, Neyts E, Gijbels R, and van der Mullen J. Gas discharge plasmas and their applications. Spectrochim Acta Part B, 2002; 57(4): 609-658.

10. Liu Z, Li S, Chen $Q$, Wang Z, Yang L, and Li B. The Spatiotemporal Pattern Formed in an DielectricBarrier-Discharge Oxygen Plasma. IEEE T Plasma Sci, 2011; 39(11): 2130-2131.

11. Nehra V, Kumar A, and Dwivedi HK. Atmospheric NonThermal Plasma Sources. Int J Engineer, 2008; 2(1): 53-68.
12. Khadre MA, Yousef AE, and Kim JG. Microbiological Aspects of Ozone Applications in Food: A Review. J Food Sci, 2001; 66(9): 1242-1252.

13. Das E, Gurakan GC, and Bayindirli A. Effect of controlled atmosphere storage, modified atmosphere packaging and gaseous ozone treatment on the survival of Salmonella Enteritidis on cherry tomatoes. Food Microbiol, 2006; 23(5): 430-438.

14. Kim JG, Yousef AE, and Dave S. Application of ozone for enhancing the microbiological safety and quality of foods: a review. J Food Protect, 1999; 62(9): 10711087.

15. Facta $M$, bin Salam Z, and Bin Buntat $Z$. The development of ozone generation with low power consumption. Proceedings of 2009 Innovative Technologies in Intelligent Systems and Industrial Applications. 25-26 July 2009. pp. 440-445.IEEE, Malaysia.

16. Zhang X, Lee BJ, Im HG, and Cha MS. Ozone Production With Dielectric Barrier Discharge/ : Effects of Power Source and Humidity, IEEE T Plasma Sci, 2016; 44(10): 1-9.

17. Kogelschatz $U$, Eliasson B, and Hirth M. Ozone Generation from Oxygen and Air: Discharge Physics and Reaction Mechanisms. J Int Ozone Assoc, 1998; 10(4): 367-377.

18. Kitayama J. and Kuzumoto M. Analysis of ozone generation from air in silent discharge. J. Phys. D: Appl Phys, 1999; 32(23): 3032

19. Liao LB, Chen WM, and Xiao XM. The generation and inactivation mechanism of oxidation-reduction potential of electrolyzed oxidizing water. J. Food Engineer, 2007; 78(4): 1326-1332.

20. Wang $G$, Zhu R, Yang L, Wang K, Zhang Q, Su X, Yang $B$, Zhang J, and Fang J. Non-thermal plasma for inactivated-vaccine preparation. Vaccine, (2016); 34(8): 1126-1132.

21. Gaunt L, Higgins S, and Hughes J. Decontamination of surface borne bacteria by ionized antimicrobial vapours. J. Electro., 2005; 63(6-10): 809-814.

22. Fletcher LA, Gaunt LF, Beggs CB, Shepherd SJ, Sleigh PA, Noakes $C J$, and Kerr KG. Bactericidal action of positive and negative ions in air. BMC Microbiol., 2007; 7(32): 1-9. 